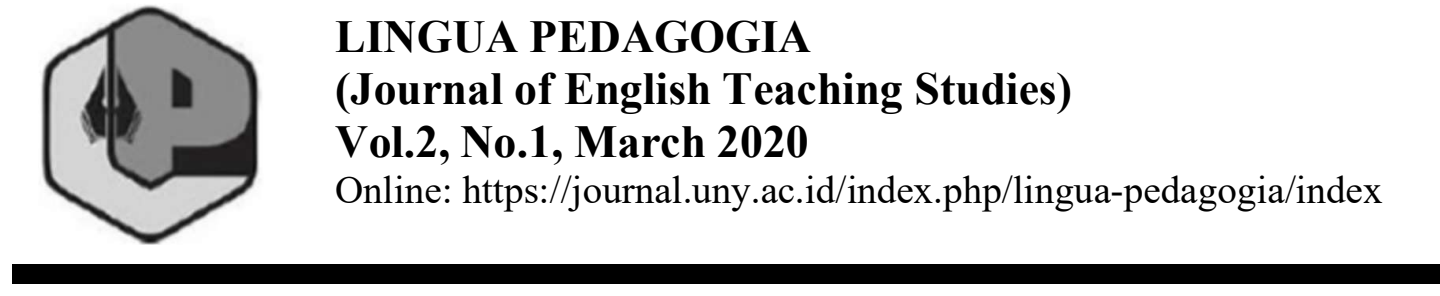

\title{
Improving the Speaking Learning Process of Grade VIII Students Through Games
}

\author{
Chatarina Heny Eka Purnamu \\ chaterinahenny@yahoo.com, \\ Yogyakarta State University
}

\author{
Joko Priyana \\ j_priyana@yahoo.com \\ Yogyakarta State University
}

\begin{abstract}
This study was aimed at improving the speaking learning process to the students of grade VIII at SMPN 3 Cilacap through games in the academic year of 2013/2014. This classroom action research was carried out in two cycles. The cyclical design consisted of four main steps: (1) planning, (2) action, (3) observation, and (4) reflection. Various games with some supporting activities were implemented in this study. The data were gathered through observations, interview, rating, video/audio recording, and performance tests. The data were analyzed using the interactive qualitative data analysis and descriptive statistics. The findings show that games which are set up properly involved preliminary activities, game play and closure, together with some supporting activities are able to improve the speaking learning process. The implementation of games is effective to lessen the interference of the native language, lessen the students' domination in the class, encourage the students' initiation to speak English, give the students plenty of opportunities to speak as often as possible and encourage the students to focus on fluency rather than accuracy, encourage the students' confidence, and increase the students' involvement in the learning process. These improvements lead to the improvements of the students' speaking skills. The students' average score in performance test before implementing the actions is 63,39 while after implementing the actions is 81,64 . It shows that it increases about $28,77 \%$. It can be inferred that the students' speaking skills improved after the implementation of the games.
\end{abstract}

Keywords: speaking skill, games, classroom English, media, pronunciation drills, group working, feedback, rewards.

\section{Introduction}

English is one of the language which is taught in most of countries in the world and so is in Indonesia. The Indonesian government places it in the national education curriculum for junior high school to university. The national education goals of English language learning for SMP/MTs are stated in Permendiknas (the act of the minister of national education) number 22 of 2006 . One of the goal is to develop the English communicative competences, both in oral and written, in order to reach functional literacy. It means that students are demanded to be able to communicate in written and speech in solving their problems in their daily life. To reach the goal, the language teaching must be focused on the learning process rather than the teaching of language, so the emphasis is not only on 
linguistic competence of the language learners but also on the development of their communicative ability. Students need to learn speaking skill to develop their communicative ability, therefore learning speaking skill is so important for SMP students. One of the language experts, Thornbury (2005) supports that speaking is an important skill to be learned, he says," Speaking is a skill, and as such needs to be developed and practiced independently of the grammar curriculum." It means that learning speaking must be practiced without too emphasizing on grammatical structure. It more emphasizes on fluency rather than on accuracy.

In order to know the students' basic competence, researcher did a preliminary observation on August 2013. As a result, the students' proficiency was considered unsatisfactory. It was only about $30 \%$ of the intended language expressions can be mastered well by some students. They also had difficulties in understanding short functional text and short monolog of descriptive text and procedure text, they could not practice them accurately and fluency.

Thus, there is an obvious gap between the intended language learning stated in curriculum with the current level of the students' performance. Therefore, researcher and collaborators are curious to find some solutions of the problems.

There are some problems identified related to the result of preliminary observation done in SMPN 3 Cilacap, but this study only focused the following problem:

1) Students were passive during the process of teaching and learning speaking in the classroom

2) Students lacked interest in the teacher's presentation during teaching learning process

3) Students lacked motivation in speaking English during the language learning process.

The condition above caused the speaking learning process did not run well. Therefore, this research focused on the way to encourage the students' interest and motivation, so that the students participated actively in speaking learning process.

Teaching is the most important thing in learning process. Through teaching a teacher can help the students to understand about the lesson given. Nunan (as cited in Kayi, 2006) says, "Teaching language, especially speaking skill, for ESL/EFL students is not an easy job." Speaking is a complex process. According to Richards and Renandya (2002, p. 204) the effective oral communication requires the ability to use the language appropriately in social interactions that involves not only verbal communication but also parallinguistic elements of speech such as pitch, stress, and intonation. Moreover, nonlinguistic elements such as gestures, body language, and expressions are needed in conveying messages directly without any accompanying speech. Therefore a guidance of teaching speaking is needed. Brown (2007, pp. $331-332$ ) suggests the principles for teaching speaking skills as a guidance in teaching speaking. The principles are as follows:

1) Focus on both fluency and accuracy, depending on the objective

2) Provide intrinsically motivating techniques

3) Encourage the use of authentic language in meaningful contexts

4) Provide appropriate feedback and correction 
5) Capitalize on the natural link between speaking and listening

6) Give students opportunities to initiate oral communication, and

7) Encourage the development of speaking strategies.

Kayi (2006) says that," The goal of teaching speaking should improve students' communicative skills, because only in that way, students can express themselves and learn how to follow the social and cultural rules appropriate in each communicative circumstance". Therefore, in teaching the students, teacher should not only guide the students to know how to produce speech sound or specific points of language such as grammar, pronunciation, or vocabulary but also teach them to understand when, where, why and in what ways to produce language which is appropriate with the social and cultural rules in each communicative circumstance.

According to Brown (2007, p. 327-330) there are some activities that can be applied in teaching speaking, they are: imitative activity, intensive activity, responsive activity, transactional dialog, interpersonal dialog, and extensive/ monolog.

To reach the goal of learning speaking for junior high school, students should master subskills as stated in the KTSP's Basic Competence and Competence Standard. The subjects of this research is the year eight students of Junior High School in semester one, so the scope of the speaking learning materials should be mastered are as follows:

1) The students should be able to express meanings on very simple transactional and interpersonal conversations and to express meanings on functional spoken texts and very short monologues in the form of descriptive and recount texts in order to interact with the nearest environment

2) The students should be able to express asking for, giving and refusing services/helps, asking for, giving and refusing things, recognizing and denying facts, asking for and giving opinion, accepting and refusing invitation, expressing agreement and disagreement, and admiring and congratulating

Students of junior high schools are normally in the age of 11 to 15 years old. They can be categorized as teenagers or adolescents. Generally, in the age of teens, they have specific characteristics as explained by Harmer (2012, p. 89- 91), they are:

1) Teenagers can start to think in abstract terms

2) Many students become passionate about the things that interest them

3) Many adolescent students have a large amount of energy

4) Many adolescents want and need peer approval far more than they want and need to the approval of the teacher

5) Some students have unresolved problems with sef-esteem

6) Many adolescents are extremely concious of their age and find it irritating when adults continue to teach them as children.

Therefore, teacher should create a very special set of considerations applies to teaching teenagers. Harmer (2012, p. 89) suggests some tips for teaching teenagers: 
1) Encourage teenagers to have opinions and to think critically and questioningly about what they are learning

2) Use the students' own knowledge and experience as much as possible

3) Treat the students like adults but remember they are still children

4) Encourage the students to take responsibility for their own learning

5) Be super-organised! Teenagers like to know what they are doing and why

6) Be consistent when there are discipline problems. Criticise the behavior, not the students.

There are some possible ways to improve the speaking learning process promoted by some experts. One of the experts, Kayi (2006) promotes some activities that can be applied in the speaking learning process such as discussion, role play and simulation, Communication games, story telling, picture narrating and so forth.

The goal of English teaching and learning will be reached if the teaching and learning process is success or in a good quality, and it can run well by perceiving and internalizing connections between practice (choices you make in the classroom) and theory (principles derived from research). Some experts, Harmer (2007, p. 123 - 124), Brown (2007, p. 331332), and Picollo (2013) promoted some indicators to determine a good speaking learning process. The indicators are:

1) The students have opportunity to speak as often as possible

2) The students are all participating fully in the learning process

3) The students' participation is not dominated by a few talkactive students

4) The students initiate to speak in target language

5) The students can minimize the interference of the native language

6) The students speak English confidently

7) The students are more focus on fluency rather than accuracy

8) The students get sympathetic and useful feedback from the teacher during the learning process

9) The students get rewards from teacher during the learning process.

There are many techniques in teaching speaking proposed by some experts, but to gain meaningful learning, the technique used must be based on the students' learning context. Dick and Carey (2013) convey that learning context can be conducted by doing a learner analysis and a context analysis. Relevant to this research, for a learner analysis researcher describes the students' mastery level in English of the year eight students of SMPN 3 Cilacap and their characteristics and for a context analysis, researcher describes the school environment and the infrastructure of SMPN 3 Cilacap.

Based on the preliminary observations, it found that the students' English proficiency was considered in low level, because they rarely given opportunity to speak up. The activities in the classroom was teacher-centre. Besides the learning atmosphere was unsupported too, there were several talkactive students who dominated the activities. This condition caused the other students became unconfident to speak up. Then lack of teaching media used by the teacher and the monotonous presentations also caused the students became uninterested and 
unmotivated to be involved in the lesson. They became passive during the speaking learning process.

Cilacap is an industrial city. Most of the industries operating in Cilacap owned by foreign investors. Working in these industries are the ideal of many students of SMPN 3 Cilacap. To support the students' ideal, improving the students' speaking skills is needed.

Based on the condition above, games are considered as the applicable technique to improve the speaking learning process to the students of grade VIII at SMPN 3 Cilacap, because the characteristics of games are amusing, highly motivating, challenging, fun-filled and relaxing atmosphere, cooperative, and students-centred activities. It is supported by some experts, such as: Erzos (2000, p.1) who states 'Well-chosen games are invaluable as they give students a break and at the same time allow students to practice language skills. Games are highly motivating since they are amusing and at the same time challenging. Furthermore, they employ meaningful and useful language in real contexts. They also encourage and increase cooperation'. Uberman (as cited in Chen, 2005) also states that 'Games offer students a fun-filled and relaxing learning atmosphere'.

According to Hadfield (1996, p.1)," Game is an activity with rules, a goal and an element of fun." It means that the game activities with certain rules are done in fun and relax atmosphere in order to reach certain goal.

After disscusing with the collaborators of this research, some communicative games adapted from Hadfield were used for this research because the learning materials in these games are relevant with the syllabus of teaching speaking for the students grade eigth semester one and the games are intended for the beginner so they are simple and easily conducted.

\section{Method}

This research was conducted by applying the Classroom Action Research (CAR) method. This action research typically involves small scale investigation in his own classroom, consisting of a number of phases which often recur in cycles. It is characterized by its steps called: Planning, Acting, Observing, and Reflecting. This research used Cyclical action research suggested by Madya (2009, p.67) modified from Burns (1999, p.33). 


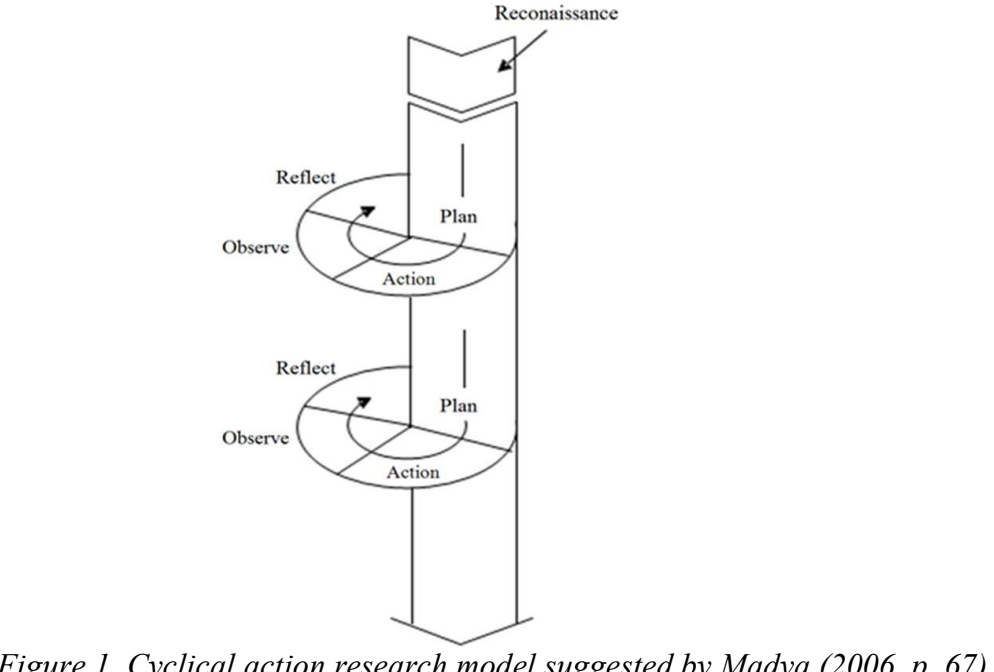

The first discussion was held on $3^{\text {rd }}$ August 2013 to determine the thematic concern of the study and plan the actions dealing with the existing problems. Furthermore, some discussions were held before and during the research. At the end of every cycle, a discussion was held to evaluate the whole actions that had been conducted and to formulate the actions for the next cycle. The implementation of the actions for each cycle was done from November 2013 to December 2013 referring to the English lesson schedules of class VIII B and the educational calender of the school.

\section{Plan of Action}

Some games adapted and modified from Hadfield (1999, p.6- 7) were considered to be implemented in the actions, then for the last action, an English Competition was held in order to make the students being more creative and confident in practicing their Englishspeaking skill. After planning the actions, I developed a course grid, teaching materials, and lesson plans, and students' whorksheet based on the data gathered in preliminary observations.

In preparing the games, some games adapted and modified from Hadfield (1999, p.6- 7) were selected based on the standard of competency and basic competence for speaking skill in the curriculum for Junior High School grade VIII semester 1. The implemented games were chosen by considering some factors proposed by Sugar and Sugar (2002, p.11-18). The factors were (1) target audience, (2) learning outcomes, (3) game playing time, (4) the whole course, and (5) game variations. Before implementing the games, some preparations were done. The game preparation used in the actions was adapted from Sugar and Sugar (2002, pp. 29- 38), they were: game preparation and game setup. Game preparation covered assembling the game accessories, while game setup involved the preliminary activities, game play and closure.

Action

The action was based on the plan made in the previous stage. I implemented the actions in teaching learning process and my collaborators were as observers. These actions were implemented in two cycles, and each cycle implemented one unit tasks which were done in twice meetings. 


\section{Observation}

The collaborators observed the students' activities during the speaking learning process through games based on the observation sheet provided. They also made field notes to records the situation happened during the teaching learning process.

\section{Reflection}

In this step, my research team evaluated the plan that was implemented in each meeting by discussing the observation and field notes that have been made by the collaborators. The result of the discussion was served as an evaluation.

\section{Techniques and Instruments of Collecting Data}

\section{Observation using observation guide}

The observation sheet related to the indicators of good speaking learning process. This observation sheet was in the form of checklist. It was fulfilled by the collaborators, and the results were used to determine whether the speaking learning process through games could be improved or not.

\section{Questionnaires using questionnaire guidelines.}

It was used to find out the problem faced by the studentsand the English teacher in undergoing the teaching and learning process, and the students' feeling and opinions toward the English teaching and learning process through games in each cycle.

\section{Interview using a voice recorder}

Interviews were used to get data from the students, practitioners, and other stakeholders in the school to complement data obtained from the observations. These interviews done in preliminary observation, during the implementation of the actions in each cycle and after the research was ended.

\section{Documentation using camera and video recording}

Photographs, and video recording were used to document the actions. Photographs were used to ilustrate teaching techniques, provide a permanent visual resource for classroom tasks, and so on. While video recording was used to capture in detail naturalistic interactions.

\section{Performance test using test oral proficiency scoring modified from Brown}

The performance tests were given to know the students' speaking competence before and after the implementation of the actions. This research used the oral proficiency score modified from Brown (2004: 172- 173) as a reference to measure the results of the students' speaking performance test. 


\section{Techniques of Data Analysis}

This research used the qualitative and quantitative techniques of data analysis. The qualitative data were analyzed based on the process of data analysis adapted from Burns (1999, pp. $157-160)$, they were assembling the data, coding the data, comparing the data, building interpretation and reporting the outcomes.

The quantitative data of this research were analyzed using descriptive statistics. The data obtained from the observation sheets, the rating of the students' opinion of the implemented games, and the students' needs were analyzed using Linkert scale and numerical rating scale proposed by Widoyoko (2013, pp. 104- 123). To measure the results of performance test before and after the implementation of the actions, the oral proficiency scoring modified from Brown (2004, pp. 172-173) was used as a reference.

\section{Research Findings and Discussion}

Based on the preliminary observation, it found that the students' speaking skills was considered in low level, because they rarely given opportunity to speak up. The activities in the classroom was teacher-centre. Besides the learning atmosphere was unsupported too, there were several talkactive students who dominated the activities. This condition caused the other students became unconfident to speak up. Then lack of teaching media used by the teacher and the monotonous presentations also caused the students became uninterested and unmotivated to be involved in the lesson. They became passive during the speaking learning process. Therefore, my research team planned to implement the games which was set up properly, together with some supporting activities in each cycle.

\section{Report of cycle 1}

Cycle 1 was carried out in two meetings, on $15^{\text {th }}$ November 2013 and $21^{\text {st }}$ November 2013. In this cycle, students learned about how to express asking for something, giving something and refusing something. During the implementation of the actions in the first cycle, I acted as a teacher and there were two English teachers acting as observers. The data were collected using classroom observations, interviews, questionnaires and documentation. They were four games played in cycle 1, namely: Spelling Lotto Game, Collector Game, Restaurant Game and A Restaurant Role Play Game.

In cycle 1 , the implementation of games for speaking practice was accompanied by some supporting activities, such as: implementing classroom English in learning process, giving pronunciation drill before playing the game, the using of teaching media to assist the teaching and learning process and to attract the students attention, implemeting pair works and group works in doing learning activities, and the implementation of giving feedback and reward to encourage the students' motivation. The improvement in each meeting is presented below.

All students played the games enthusiastically, they really enjoyed them. The games provide students opportunity to practise speaking a lot and encourage the students to participate actively during the lesson. However, the implementation of games in the first meeting of cycle 1 was considered ineffective because "Spelling Lotto Game" consumed a lot of time to practise and made students bored easily. Emphasizing in teaching spelling was ineffective for junior high school, because it was only used for certain case in learning process. While "Collector game" could not run well because of limited spare time. Besides, many students 
seemed broke the rules in playing games. They preferred speaking in native language in playing the game other than the intended expressions. So when teacher asked them to speak English, they did it unconfidently.

My team made some revisions in implemented games for the second meeting of cycle 1 . I asked the students to keep the rules of games strictly and practised speaking English-especially for the intended expression, not only in playing the game but also in communicating each other. The implementation of games in the second meeting of cycle 1 could be considered effective enough to improve the speaking learning process. The students really enjoyed the games, they played them under fun and rilax atmosphere. Especially in playing "A Restaurant Role Play Game" the students looked very enthusiastic conducting the games, they became more creative in preparing their owned media and in performing the dialogs given. They made some improvisations in performing the game, so it looked more natural and livelier. All students participated actively and practising speaking a lot. Some students became more confident in speaking English and they also tried to communicate using English for simple expressions though many students often misspronounce for some words.

Implementing classroom English during speaking learning process was effective to encourage the students' initiation in speaking English because as often as I spoke in English the students tried to speak in English too. In cycle 1, some passive students began initiating in answering the teachers' questions. Some students were willing to do the exercises on the whiteboard. But many students still unconfident to speak up in English, they preferred speaking in Indonesia to communicate each other, and they asked me frequently to translate into Indonesia if they did not know what I meant.

Giving pronunciation drills before playing games was effective for anticipating the students faced speaking problems during implementing the games. In cycle 1, the students had learned how to read the phonetic transcription of English words. This knowledge was really helped the students to learn pronounciation by themselves by checking it in a dictionary. All students learned pronunciation drills enthusiastically. At the end of this cycle, the students' pronunciation ability for some students improved, but others still had difficulties in it. They also faced difficulties in intonation.

Implementing some teaching media were very effective in teaching and learning process. They really helped students to understand the learning materials easily and They attracted the students' attention so that they enjoyed the teacher's presentation and the learning process. Some teaching media used in this study such as: power point presentations, cards, real things, video and so forth. Power point presentation was implemented during the learning process, it attracted the students' attention and helped the students in understanding the learning materials easier. Cards were used during playing games. They really effective to encourage the students work cooperatively, minimize the domination of several talkactive students since they had to play in turn, encourage the students to participate actively, and so forth. While real things were used in pre teaching activities to attract the students' attentions and led them to guess the topic of the lesson, it also could be used to check the students' comprehension for the last lessons. Videos were presented before playing the game. This presentation was much more effective than giving the students lengthy explanations or demonstration. These videos were simple and contextual, so they were understandable. So it can be inferred that the using of media in teaching and learning process is usefull. This statement is supported by Smaldino, Sharon E. (2007,p. 6) who states,"The purpose of media is to facilitate communication and learning". These media would be implemented in cycle 2 . 
The implementation of pair work and group work in the speaking learning process was very effective to encourage students' interaction in doing learning activities. By putting the students in a pair work or group work, they would have plenty of opportunities in speaking practise since the amount of speaking time was increased. It was effective to reduce the students' domination in speaking activities since they had to tolerate with their friends' difficulties. They did the activities in a group so that they would not be afraid or worried making mistakes. This condition could increase the students' confidence in speaking English and encouraged them to participate fully in the speaking learning process.

In cycle I, giving feedbacks and rewards were really effective to motivate the students to get more achievements. They looked so happy when they recieved the rewards. Giving feedback and rewards would be implemented too in the next cycle. Verbal praises, positive encouragement and real prizes would be given to motivate the students to get the best performance.

The reflection was considered the improvements of the speaking learning process which could be seen from the observation sheets filling by the collaborators during the actions in every meetings in cycle 1 and the analysis of the students' questionnaires about their opinion in the use of implemented games.

To enrich the data, I also asked the students to answer the similar questionnaires containing the students' opinion about the use of games in speaking learning process. There were two choices, agree and disagree with the statements given. If they agreed with the statements, they had to put a tick or cross the smile picture and vice versa. The questionnaire was distributed in the last meeting of cycle 1 .

Based on the data analysis, it could be inferred that most of the students agreed that games were effective to encourage the speaking learning process running well as presented below.

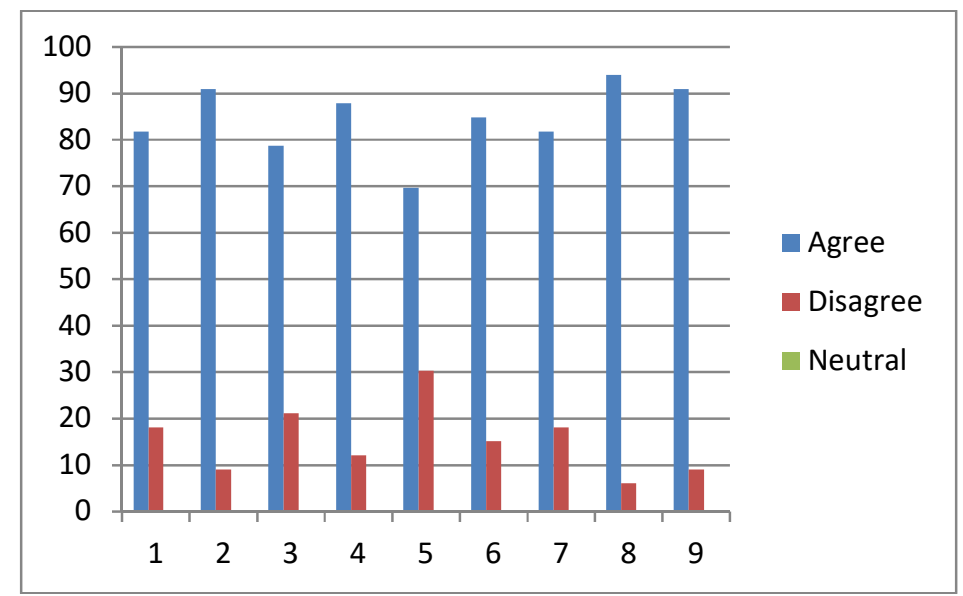

Figure 2. Rating students' opinion about the implementation of games in the process of teaching and learning speaking in cycle 1.

The indicators of the figure above were (1) The games provide opportunities for the students to speak a lot, (2) The games support the students participate actively in the learning process, (3) The students' participation is not dominated by a few active students during the process of the games, (4) The games support the students to initiate speaking in English, (5) The games 
lead the students minimizing the interference errors of the native language, (6) The games support the students speaking in English confidently, (7) The games support the students more focus on fluency rather than accuracy, (8) Students get symphathetic and useful feedback from the teacher during the process of the games, (9) Students get reward from the teacher during the learning process.

From the data analysis, it could be inferred that the implemented games in cycle I was effective to encourage the speaking learning process in class VIII B running well.

However, my research team noticed that the games have not really successfully encouraged the students to speak English fluently and confidently yet since they still faced some difficulties in speaking ability. The domination of several students was found during the question and answer activities, while in playing the games, the domination could be reduced, especially in the second meeting of cycle I. The interference of the students' native language has not been able to minimize yet, they spoke English only for the intended expressions.

\section{Report of Cycle 2}

The actions of cycle 2 were implemented in two meetings, on $26^{\text {th }}$ and $29^{\text {th }}$ November 2013. The topic of this cycle was entertainment and friendship with the language functions inviting someone, accepting and refusing invitation. There were two games that would be implemented in this cycle, they were "Blind Date Game" and "An English Competition Game". The implementation of games in cycle 2 were carried out together with some supporting activities, they are implementing some variations in games, using the classroom English in the speaking learning process optimally, implementing some variation in grouping the students, implementing the pronunciation drill and various intonation optimally, using more various teaching aids in the speaking learning process, and immediate feedback and rewards given to motivate the students. The results finding in cycle 2 are presented below.

In cycle 2, I made some variations in implementing the games, The first variation, I offered a game which was carried out in a whole class activities, so I change the students' seat setting into the form of letter U. After implementing it, my research team noticed that the implementation of the game was ineffective since teacher face problem in monitoring the studexnts' activities. It also found that the letter U seat setting was ineffective for class with a big number of students, because it was not wide enough to move from one place to another. So for the second game in cycle 2, was conducted in a small group. It was aimed to monitor the students' activities easier. I made a little variation for the second game. It was a kind of role play, but I modified it into a competition game with the students' classmate as the accesors. After implementing this game, my research team noticed that there were great improvements in this cycle. All students really performed well, the spoke fluently and confidently. There was no domination of several students anymore, all students participated fully during the learning process, they became more active in the speaking learning process. The interference of their native language could be minimized, they spoke indonesia if only they did not know the difficult words. Overall, it could be said that the speaking learning process ran well.

This implementation of classroom English was applied maximally in cycle 2. I spoke English to the students not only during the learning process- that was in beginning, in running and in ending the lesson, but also in outside the classroom. I did it whenever I met them at school. As a result, the students became more accustomed speaking in English, their initiation of 
speaking English increased and they became confident enough to participate fully in the learning process.

In cycle 2, the pronunciation drills were given with a little variation in order to made the students were able to correct the pronunciation by themselves. By doing this activities the students would remember longer. Various intonation also learned in this cycle. As a result, at the end of cycle 2, my team noticed that there was significant improvements of the students' ability in pronounce words. Most of them could pronounce words related to the topic well. They only misspronounced some words during performing role play competitions.

During the implementation of the study, the students prefered working in pairs or in small group rather than in a big group. They were more familiar with it. Moreover, the teacher could monitor them more easily.

Giving symphatetic and usefull feedback during the learning process was effective to motivate the students participated actively during the learning process. By getting feedback, they would know their mistake and the correct forms, so that they would perform better in future. They would also know how well they were and it motivate them to improve themselves. Giving rewards for the students' accomplishments was really effective to motivate them. It could be seen, especially in implementing the last game "An English Role Play Competition Game", the students were very motivated to perform as well as they could do. Besides getting prestige when they won the competition, they did it for prizes provided by the teacher.

To enrich the data, I also asked the students to answer the similar questionnaires containing the students' opinion about the use of games in speaking learning process. There were two choices, agree and disagree with the statements given. If they agreed with the statements, they had to put a tick or cross the smile picture and vice versa. The questionnaire was distributed in the last meeting of cycle 2 . The result of the data analysis are presented in the following figure.

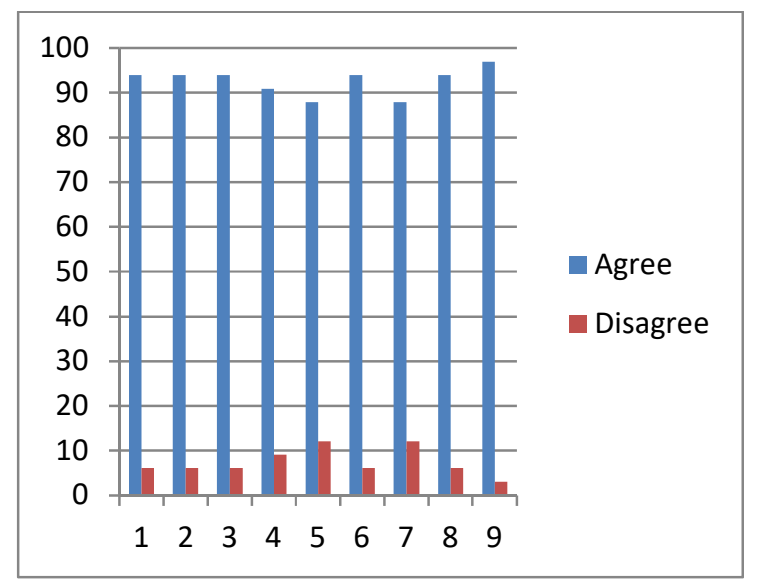

Figure 3. Rating students' opinion about the implementation of games in the process of teaching and learning speaking in cycle 2

The indicators of the figure above were (1) The games provide opportunities for the students to speak a lot, (2) The games support the students participate actively in the learning process, (3) The students' participation is not dominated by a few active students during the process of the games, (4) The games support the students to initiate speaking in English, (5) The games 
lead the students minimizing the interference errors of the native language, (6) The games support the students speaking in English confidently, (7) The games support the students more focus on fluency rather than accuracy, (8) Students get symphathetic and useful feedback from the teacher during the process of the games, (9) Students get reward from the teacher during the learning process.

The results of this research shows that there were some improvements in the speaking learning process after implementing games accompanied by some supporting activities. The improvements led the students' speaking skill improved too. The results of this research show that there were some improvements in the speaking learning process after implementing games accompanied by some supporting activities.

From the quotation above, it could be inferred that There were some improvements in speaking learning process in VIII B class. After implementing the games, the speaking learning process ran well and the students' speaking ability improved too.

\section{Before the actions}

The existing condition before implementing the actions were (1) The students were uninterested in the teacher's presentation in the classroom because the teaching techniques used was monotonous and uncommunicative, (2) The students' motivation was low because they were not confident to speak up, the class activities often dominated by some active students and they rarely got usefull feedback and rewards from their teacher, (3) The students were passive in speaking learning process because they rarely given opportunity to practise their speaking and to participate in the learning process.

\section{The Changes in cycle 1}

After implementing some actions in cycle 1, some Improvements were occurred, they were (1) Some passive students began to initiate in answering the teacher's questions, (2) Many students participated actively because they gave opportunity to speak a lot, (3) The use of media in teaching and learning process made all students interested in involving the learning process, and (4) Giving feedback and rewards motivated most of the students to get better achievement.

However there were some conditions that shoul be improved in cycle 2, they were (1) Some students still spoke in Indonesian and javanese language frequently in communicating each other, (2) Some students could not speak English fluently and confidently, (3) Several talkactive students dominated in certain activities in the learning process, (4) Some students preferred making a group with students whom they wanted to.

\section{The Changes in cycle 2}

After implementing the revised plans in cycle 2, some improvements were occurred during the process of teaching and learning speaking, they were (1) many students initiated to answer the teachers question volunteerly, (2) all students participated actively in practising the target language during the learning process, (3) most of the students practising the target language fluently and confidently in communicating each other, (4) most of the students could speak English with intteligible pronunciation, (5) all students worked cooperatively, there was no any domination during the learning process, (6) most students could mingle and interact 
very well with one another without worrying with whom they work, this condition could encourage the students' confidence and also lessen the students' dominantion during the learning process, and (7) all students motivated to get the best achivements.

The students' agreement about the effectiveness of games in the process of teaching and learning process in cycle 1 and cycle 2.

The improvemnets of the students' agreement toward the effectivenes of implementing games in the process of teaching and learning speaking were presented in the figure below.

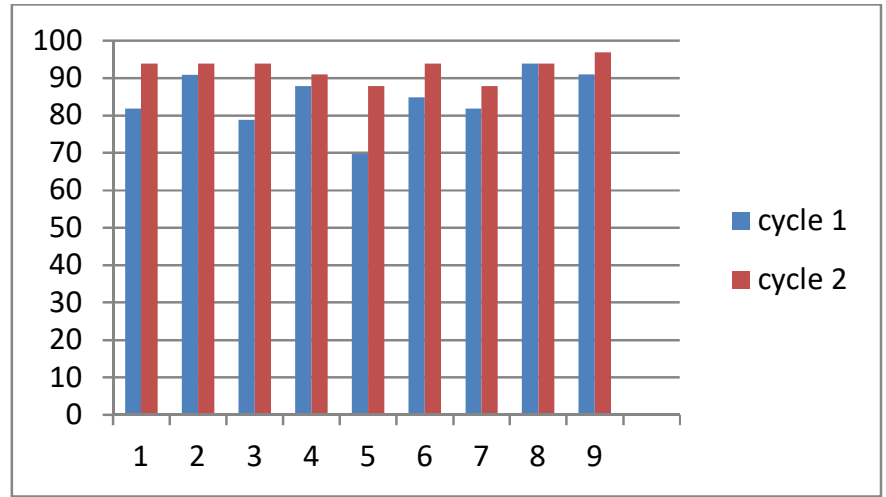

Figure 4. The summary of the success in cycle 1 and cycle 2 based on the students' agreement about the effectiveness of implementing games in learning process.

The indicators of the figure above were (1) the games provide opportunities for the students to speak a lot, (2) the games support the students participate actively in the learning process, (3) the students' participation is not dominated by a few active students during the process of the games, (4) the games support the students to initiate speaking in English, (5) the games lead the students minimizing the interference errors of the native language, (6) the games support the students speaking in English confidently, (7) the games support the students more focus on fluency rather than accuracy, (8) students get symphathetic and useful feedback from the teacher during the process of the games, (9) students get reward from the teacher during the learning process.

The data analysis of the comparison between the average score of performance test before and after the implementation of the actions.

The first performance test was carried out at $11^{\text {st }}$ November 2013. The performance test was given before implementing the actions. The results of the test showed that the students' average score is 63.39. The second test was carried out at $3^{\text {rd }}$ December 2013. The performance test was given after the implementation of the actions. The results of the test showed that the students' average score is 81.64 . It shows that the results of the performance test increases about $28,77 \%$. Therefore It can be inferred that the students' speaking skills improved after the implementation of the games.

Based on the data above, it could be inferred that there were significant improvements of the speaking learning process from cycle 1 to cycle 2 and these improvements led the improvements of the students' speaking skills that could be seen from the results of the performance test before and after the implementation of the actions. 


\section{Conclusion}

The findings show that games which were set up properly involved preliminary activities, game play and closure together some supporting activities can be implemented to improve the process of teaching and learning speaking to the students of grade VIII at SMPN 3 Cilacap. The results of the actions are as follows. First, the implementation of games together the using of classroom English during the process of teaching and learning speaking can lessen the interference errors of the native language, encourage the students' initiation to speak English, give the students plenty of opportunities to speak English as often as possible and encourage the students to more focus on fluency rather than accuracy. Second, The implementation of games together giving pronunciation drills before playing the games makes the students more confident to speaking English. Third, The implementation of games together using of the media, giving feedback and rewards toward the students' performance are able to increase the students' participation during teaching and learning process. Fourth, the implementation of games along with group work are able to lessen the students' domination in class. These improvements lead to the improvement of the students' speaking ability which can be seen from the result of the performance test before implementing the actions It shows that the students' speaking ability improves after the implementation of the games during the process of teaching and learning speaking to the students of grade VIII B at SMPN 3 Cilacap at the academic year of 2013/2014.

\section{References}

Brown, H.D. (2004). Language assessment: Principles and classroom practicers Pearson Education Company.

Brown, H.D. (2007). Teaching by principles: An interactive approach to language pedagogy. $\left(3^{\text {nd }}\right.$ edision $)$ : Pearson Education Company.

Chen, I-Jung. (2005). Using Games to Promote Communicative Skills in Language Learning. The Internet TESL Journal, Vol.XI(2), 1-1. http://itestlj.org/Tecniques/Chen-Games.html.

Depdiknas. (2006). Peraturan Menteri Pendidikan Nasional Nomor 22 Tahun 2006 tentang Kurikulum Badan Standar Nasional Pendidikan (BSNP) Standar Isi, Standar Kompetensi dan Kompetensi Dasar.

Dick \& Carey. (2013). Learner and Context Analysis. Virginia Tech. http://www.itma.vt.edu/modules/spring03/instrdes/lesson5.html

Erzos, A (2000). Six Games for the EFL/ESL classroom. The Internet TESL Journal, Vol.VI(6), 1-1. http://www.iteslj.org/Lessons/Ersoz-games.html

Hadfield, J. (1996). Intermediate Communication Games. Longman.

Hadfield, J. (1999). Beginners Communication Games. Longman.

Harmer, J. (2004). The Practice of English Language Teaching.Fourth edition. Pearson Education Limited.

Harmer, J. (2007). How to Teach English. Ocelot Publishing. 
Harmer, J. (2012). Teacher Knowledge: Core Concepts in English Language teaching. Pearson Education Limited.

Kayi. (2006). Teaching Speaking Activities to Promote Speaking in Second Language._The Internet TESL Journal, Vol.XII(6), 1-1. http://itestlj.org/Tecniques/Chen-Games.html.

Picollo, L. (2013). Teaching Speaking to Second Language Students. http://suite101.com/article/teaching-speaking-to-english-second-language-students-a261761.

Richards, J. C. \& Renandya, W. A. (2002). Methodology in language teaching: An anthology of current practice. Cambridge University Press.

Sugar, S. \& Sugar, K. K. (2002). Primary Games: Experiental Learning Activities for teaching Children K-8. Jossey-Bass A Wiley Company.

Smaldino, E. S., Lowther, L. D. \& Russell, D. J. (2008). Instructional technology and Media for Learning Ninth Edision. Pearson Education Ltd.

Madya, S. (2009). Teori dan Praktik Penelitian Tindakan (Action Research). $3^{\text {rd }}$ printed. Alfabeta Company.

Thronbury, S. (2005). How to Teach Speaking. Longman.

Widiyoko, E. P. (2013). Teknik Penyusunan Instrumen penelitian. Pustaka Pelajar. 